\title{
Communicology and Culturology: Semiotic Phenomenological Method in Applied Small Group Research
}

\author{
Richard L. Lanigan ${ }^{1}$, \\ International Communicology Institute, \\ Washington, D.C., USA \\ Southern Illinois University at Carbondale, \\ Carbondale, Illinois, USA
}

\begin{abstract}
Communicology is the science of human communication where consciousness is constituted as a medium of communication at four interconnected levels of interaction experience: intrapersonal (embodied), interpersonal (dyadic), group (social), and inter-group (cultural). The focus of the paper is the group level of communication across generations, thus constituting inter-group communication that stabilizes norms (forms a culture). I propose to explicate the way in which the method of semiotic phenomenology informs the pioneering work at the University of Toronto by Tom McFeat, a Harvard trained cultural anthropologist, on small group cultures as an experimental research methodology. Rather than the cognitiveanalytic (Husserl's transcendental eidetic) techniques suggest by Don Ihde as a pseudo "experimental phenomenology", McFeat provides an applied method for the empirical experimental constitution of culture in conscious experience. Group cultures are constructed in the communicological practices of group formation and transformation by means of a selfgenerating group narrative (myth) design. McFeat's method consists of three steps of culture formation by communication that are: (1) Content-Ordering, (2) Task-Ordering, and (3) Group-Ordering, i.e., what Ernst Cassirer and Karl Jaspers call the logic of culture or Culturology. These steps are compared to the descriptive phenomenology research procedures suggested by Amedeo Giorgi following Husserl's approach: (1) Find a sense of the whole, (2) Determine meaning units, (3) Transform the natural attitude expressions into phenomenologically, psychologically sensitive expressions. A second correlation will be made to Richard Lanigan's semiotic phenomenology method following the work of Cassirer,
\end{abstract}

\footnotetext{
${ }^{1}$ rlanigan@mac.com, rlanigan@ siu.edu
} 
Jaspers, and Merleau-Ponty: (1) Description of Signs, (2) Reduction of Signifiers, and (3) Interpretation of Signifieds.

\section{Introduction}

The human science of Communicology culminates from several disciplinary developments, largely viewed as singular constitutions and foundational to differential attitudes about (1) the nature and function of philosophy and (2) the theory and method of science in apposition to human embodiment (Merleau-Ponty's reflective, reversible, reflexive consciousness of experience as experience of consciousness). In more familiar terms, the idea of Culture stands in contrast to the idea of Science, because there is a measured distinction between what human beings express and what they perceive. In Modernity, we know this situation as the emergence of (1) the distinct cultural disciplines of Linguistics (constraining Anthropology and Philology), History (constraining Sociology and Political Economy), Philosophy (constraining Logic and Psychology) over against the (2) the distinct scientific disciplines of Biology, Mathematics, and Physics. Ernst Cassirer explores this problematic of the disciplines in The Logic of the Cultural Sciences (1942/2000) where he distinguishes Culture as the perception-of-expression and Science as the perception-of-objects. Cassirer's four volume thematic of a qualitative human science is to be found in The Philosophy of Symbolic Forms (1923-1996) where his semiotic phenomenology of human communication is articulated in detail wherein Science is in the service of Culture. In this context, human understanding emerges from the semiotic matrix of communication and culture and comes to constitute the essence of the person. As a research problematic, this proposition requires explanation. "Explanations of human communication are by definition projects in metatheory construction. Just as natural languages may be used to explain themselves, the construction rules for communication systems may be used to articulate new paradigms constituting a higher logical type of communication" (Lanigan 1988: 184; Cassirer 1946/1953). The main focus of my research analysis is an explication of the method and process by which persons constitute their culture through the communication of understanding and memory.

My explication necessarily is an analysis of human science qualitative methodology (Phenomenology). Historically there have been two contemporary schools of thought on phenomenological methodology that emerged in the United States respectively in the disciplines of Psychology and Communicology. Amadeo Giorgi (2009) in the Department of 
Psychology at Duquesne University is the founding figure for the approach known as descriptive phenomenology. My own work (Lanigan 1984, 1988, 1992) in the Department of Speech Communication at Southern Illinois University established the approach of semiotic phenomenology in the discipline of Communicology. In addition, the issue of empirical and eidetic methodology within Phenomenology was introduced by Don Ihde (1970) in the discipline of Philosophy. Thus, my overall analysis takes up these various methodological issues by raising certain theory construction concerns which are, in turn, exemplified with published research drawn from the disciplines of anthropology, communicology, psychology, and philosophy.

First, it is helpful to recall the foundational review of research methodologies offered by Karl Jaspers (1913/1963: 23-37) in which he distinguishes techniques [case-studies, statistics, experiments] from logic: (1) the practical logic of research [1. Collection of individual phenomena, 2. Enquiry into connections, 3. Grasp of complex unities], and, (2) "inevitable mistakes in formal logic that have to be constantly overcome" [unlimited counting, unlimited 'ad hoc' hypothesis, acceptance of endless possibility, unlimited use of references, the impasse created by absolutes, pseudo-insight through terminology]. The failure of "practical logic" is particularly notable in standard quantitative "social science" models, while the "mistakes in formal logic" are especially apparent in qualitative "social science" models and in standard analytic "philosophy" approaches.

Given the use of logic to ground methodology, Jaspers offers a succinct statement of the approach I am taking with my analysis:

Discussion of method makes sense only when there is a concrete case to consider and when the particular effects can be shown. Discussion of method in the abstract is painful. Only a concrete logic is valid in the empirical sciences. Without factual investigations and concrete material, arguments become suspended in mid-air. There is little point in thinking up methods which are not put into practice and perhaps never can be.(Jaspers 1913/1963: 37-38).

Phenomenology sets out on a number of tasks: it gives a concrete description of the psychic states which patients actually experience and presents them for observation. It reviews the inter-relations of these, delineates them as sharply as possible, differentiates them and creates a suitable terminology. Since we 
never can perceive the psychic experiences of others in any direct fashion, as with physical phenomena, we can only make some kind of representation of them. There has to be an act of empathy, of understanding, to which may be added as the case demands an enumeration of the external characteristics of the psychic state or of the conditions under which the phenomena occur, or we may make sharp comparisons or resort to the use of symbols or fall back on a kind of suggestive handling of the data. Our chief help in all this comes from the patient's self-descriptions, which can be evoked and tested out in the course of personal conversation (Jaspers 1913/1963: 55).

For a detailed explication of the logic of conversation, see Jaspers profound analysis of human communication (Jaspers 1932/1970: 47-103).

It is a commonplace among human scientists that in many cultures the very concepts of "culture" and "communication" are embodied in the same word, e.g., Chinese 交. Why this is so sets the boundary conditions for examining the mutual influence of culture as a process of value transmission and communication as a process of value constitution. Recall that "values" are decisions displayed in verbal and nonverbal behavior. With respect to cultural transmission, Margaret Mead's (1970) work on the nature of family generations is an appropriate context for later examining Tom McFeat's experimental phenomenology project to specify the generational production, interpretation, and innovation of meaning. To appreciate the theoretical and applied advance that McFeat's research makes, it is necessary to briefly review Don Ihde's (1977) introduction to Edmund Husserl's method, the only publication to attempt an explanation of experimental phenomenology in either philosophy or the human sciences! Ihde (1977: 14) proposes that, following the direction of Edmund Husserl's phenomenological method, "the thought-experiment-or better, experienceexperiments - that are worked out here attempts to show the way in which phenomenological inquiry proceeds." 
There many theoretical principles involved in Ihde's description of his human science research. Before reviewing them briefly, it is helpful to examine an illustration of the theory construction involved as presented in Fig. 1 (compare Table 2). Basically, we need a to be aware of the methodological counterpoint to Husserl as a context for understanding. Charles S. Peirce $(2.227-229 ; 2.619-644)$ offers a logic of typology by which Maurice MerleauPonty's existential phenomenological method of (1) Description (1945/2012: 1xxi) is the use of Types, (2) Reduction (1945/2012: lxxiv) is the use of Tokens, and (3) Interpretation (1945/2012: 1xxxviii) is the use of Tones.

The Logic of Types (Charles S. Peirce)

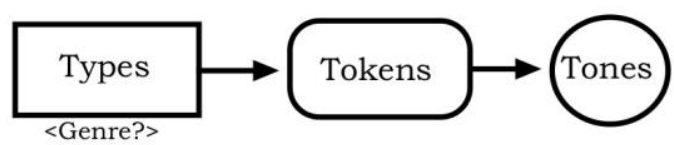

The Logic of Abduction*/Adduction** (Charles S. Peirce) $\left\{{ }^{*}\right.$ Particular, a posteriori; **Universal, a priori $\}$

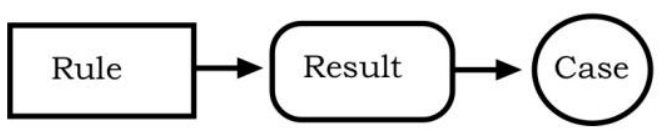

The Logic of Validity and Reliability

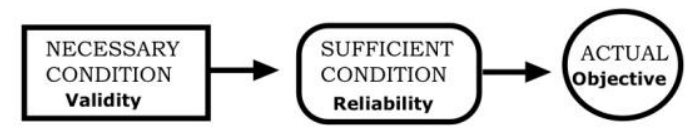

Example: Interviewing the Last Living Speaker of English

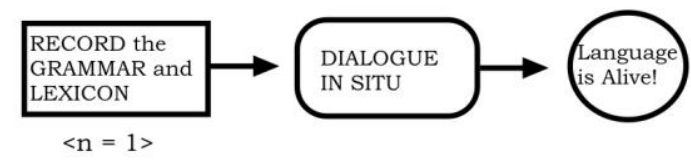

Figure 1. An Example of Research Using an " $n$ of 1"

Ihde makes several important points based on Husserl's transcendental phenomenology. First, he begins a "thought experiment" which is to examine the perceptual process involved in viewing a Necker Cube. This cube is really a drawing in two dimensions of a three dimensional image of a cube. We are not dealing with any actual object, but rather the visual representation of a mathematical idea. The unusual properties of the Necker Cube are the 
"optical illusion" images that it presents vis-á-vis the fact that multiple images are capable of perception because human brain physiology requires a shifting focus on one image at a time depending on which parts are abstracted mentally. Second, the thought experiment turns into "experience-experiments" where one Type of images can be taken as multiple Tokens, each with its own unique visual characteristics or Tone. Third, this shifting process is possible because the human consciousness understands by means of the logic of abduction (one particular experience). That is to say, an image (type of experience) of the Necker Cube is perceived in one modality (a token of experience) with one meaning (a tone of the experience). Third, only now is it appropriate to call the necker Cube a thought experiment because we can now abstract from our experience a rule of thinking (necessary condition) that validates our consciousness of experience (called "intentionality" in phenomenological method). Without this rule, we would never be able to recognize our experience when it repeats itself (result), so we conclude that that one original experience was sufficient to understand our experience (reliability). In short, to experience is to understand (a case or "state-of-affairs"). Is this example of the Necker Cube unusual? Yes, it is because the cube image is a fiction and does not occur in the natural world. But, it is the representation of an idea!

Recall now that language is a representation of the natural world and the cultural world of ideas. Ihde's presentation is merely a variation on the method used in all human sciences to investigate our human consciousness of human experience. In Fig. 1, we have a simple presentation of this complex logic as method. I use the example of a cultural linguist recording the last know speaker of the English language (imagine it is you!). By following the phenomenological method, the anthropologist is able to interview and record for posterity the semiotic-system known as the English language. This is a synoptic view of how human culture is a production, interpretation, and innovation of meaning across the generations of humankind. Culturally speaking, each generation interviews the previous generation for the meanings it wants to preserve, discard, or innovative to a new context as understanding and memory.

\section{Understanding and Communicology}

Communicology is the science of human communication where consciousness is constituted as a medium (not a channel) at four interconnected levels of interaction experience: 
intrapersonal (embodied), interpersonal (dyadic), group (social), and inter-group (cultural) as illustrated in Table 1.

Table 1. Communicology Media Levels: Each Level is a Medium.

\begin{tabular}{|c|c|c|c|c|c|c|}
\hline \multicolumn{7}{|c|}{ SPECIFICATION OF NETWORKS AT THE FOUR LEVELS OF COMMUNICOLOGY } \\
\hline ELEMENTS & ADDRESSER & CONTEXT & MESSAGE & CONTACT & CODE & ADDRESSEE \\
\hline FUNCTIONS & EMOTIVE & REFERENTIAL & POETIC & PHATIC & METALINGUISTIC & CONATIVE \\
\hline \multicolumn{7}{|c|}{ MEDIA NETWORK LEVELS: } \\
\hline $\begin{array}{l}1 . \\
\text { INTRAPERSONAL }\end{array}$ & $\begin{array}{l}\text { Embodiment; } \\
\text { Self as Mind }\end{array}$ & $\begin{array}{l}\text { Content } \\
\text { Ordering }\end{array}$ & $\begin{array}{c}\text { Store } \\
\text { Signification } \\
\text { "Within One" }\end{array}$ & $\begin{array}{l}\text { Pre-Consciousnes; } \\
\text { Pre-Reflectivity }\end{array}$ & $\begin{array}{l}\text { Synesthetic } \\
\text { Meaning }\end{array}$ & Memory \\
\hline $\begin{array}{l}2 . \\
\text { INTERPERSONAL }\end{array}$ & $\begin{array}{c}\text { Dyad } \\
\text { Relationship; } \\
\text { Self as Other }\end{array}$ & $\begin{array}{l}\text { Task } \\
\text { Ordering }\end{array}$ & $\begin{array}{l}\text { Transmit } \\
\text { Meaning } \\
\text { "One to One" }\end{array}$ & $\begin{array}{l}\text { Consciousness; } \\
\text { Reflectivity }\end{array}$ & $\begin{array}{l}\text { Cognitive } \\
\text { Meaning }\end{array}$ & History \\
\hline $\begin{array}{l}3 . \\
\text { GROUP }\end{array}$ & $\begin{array}{l}\text { Socialization; } \\
\text { Other as Self }\end{array}$ & $\begin{array}{l}\text { Group } \\
\text { Ordering }\end{array}$ & $\begin{array}{l}\text { Retrieve } \\
\text { Signification }\end{array}$ & $\begin{array}{l}\text { Present; } \\
\text { Reflexivity }\end{array}$ & $\begin{array}{l}\text { Affective } \\
\text { Meaning }\end{array}$ & Consociates \\
\hline I. EGOCENTRIC & $\begin{array}{l}\text { Task Group: } \\
\text { Identity by Rule }\end{array}$ & $\begin{array}{l}\text { Aggregate } \\
\text { Parts }\end{array}$ & $\begin{array}{l}\text { Centrifugal: } \\
\text { "One to Many" }\end{array}$ & $\begin{array}{l}\text { Competition } \\
\text { creates } \\
\text { Agony }\end{array}$ & $\begin{array}{l}\text { Names Create } \\
\text { Static Categories }\end{array}$ & $\begin{array}{l}\text { Primary Roles; } \\
\text { Leadership } \\
\text { Dominates }\end{array}$ \\
\hline II. SOCIOCENTRIC & $\begin{array}{l}\text { Affiliation Group: } \\
\text { Identity by Role }\end{array}$ & $\begin{array}{l}\text { Organic } \\
\text { Whole }\end{array}$ & $\begin{array}{l}\text { Centripetal: } \\
\text { "Many to One" }\end{array}$ & $\begin{array}{c}\text { Cooperation } \\
\text { creates } \\
\text { Harmony }\end{array}$ & $\begin{array}{c}\text { Names Create } \\
\text { Dynamic Relations }\end{array}$ & $\begin{array}{l}\text { Secondary Roles: } \\
\text { Membership } \\
\text { Dominates }\end{array}$ \\
\hline $\begin{array}{l}4 . \\
\text { CULTURE }\end{array}$ & $\begin{array}{l}\text { Co-Figurative } \\
\text { "Peers learn } \\
\text { from Peers" }\end{array}$ & $\begin{array}{l}\text { Inter-Group } \\
\text { Ordering }\end{array}$ & $\begin{array}{l}\text { Evaluate } \\
\text { Meaning }\end{array}$ & $\begin{array}{l}\text { Present; } \\
\text { Reversibility }\end{array}$ & $\begin{array}{l}\text { Conative } \\
\text { Meaning }\end{array}$ & Contemporaries \\
\hline I. SPACE & $\begin{array}{l}\text { Post-Figurative } \\
\text { "Children learn } \\
\text { from Forebears" }\end{array}$ & $\begin{array}{c}\text { Place } \\
\text { Community }\end{array}$ & $\begin{array}{l}\text { Space Binding } \\
\text { "Many to Many" }\end{array}$ & Past & $\begin{array}{l}\text { Digital Logic: } \\
\text { In-Group vs. } \\
\text { Out-Group }\end{array}$ & Predecessors \\
\hline II. TIME & $\begin{array}{l}\text { Pre-Figurative } \\
\text { "Adults learn } \\
\text { from Children" }\end{array}$ & $\begin{array}{l}\text { Non-Place } \\
\text { Community }\end{array}$ & $\begin{array}{l}\text { Time Binding } \\
\text { "Many to Many" }\end{array}$ & Future & $\begin{array}{l}\text { Analogue Logic: } \\
\text { Diffusion of } \\
\text { Innovations }\end{array}$ & Successors \\
\hline
\end{tabular}

All concepts discussed in the analysis to follow, especially those presented in the various figures and tables, are explicated in detail is specific studies that are easily referenced (Lanigan 1988, 1992, 1995a, 2010). My analysis proceeds from the point of view that human communication is a verbal and gestural form of conscious experience that is culturally contextualized as discourse. Fig.2 illustrates the standard linguistic frame of reference for discourse analysis in which each level codes the next level and constrains these correlations: (1) Parole = Intrapersonal medium, (2) Langue = Interpersonal medium, (3) Discours = Group medium, and (4) Langage = Intergroup medium. 


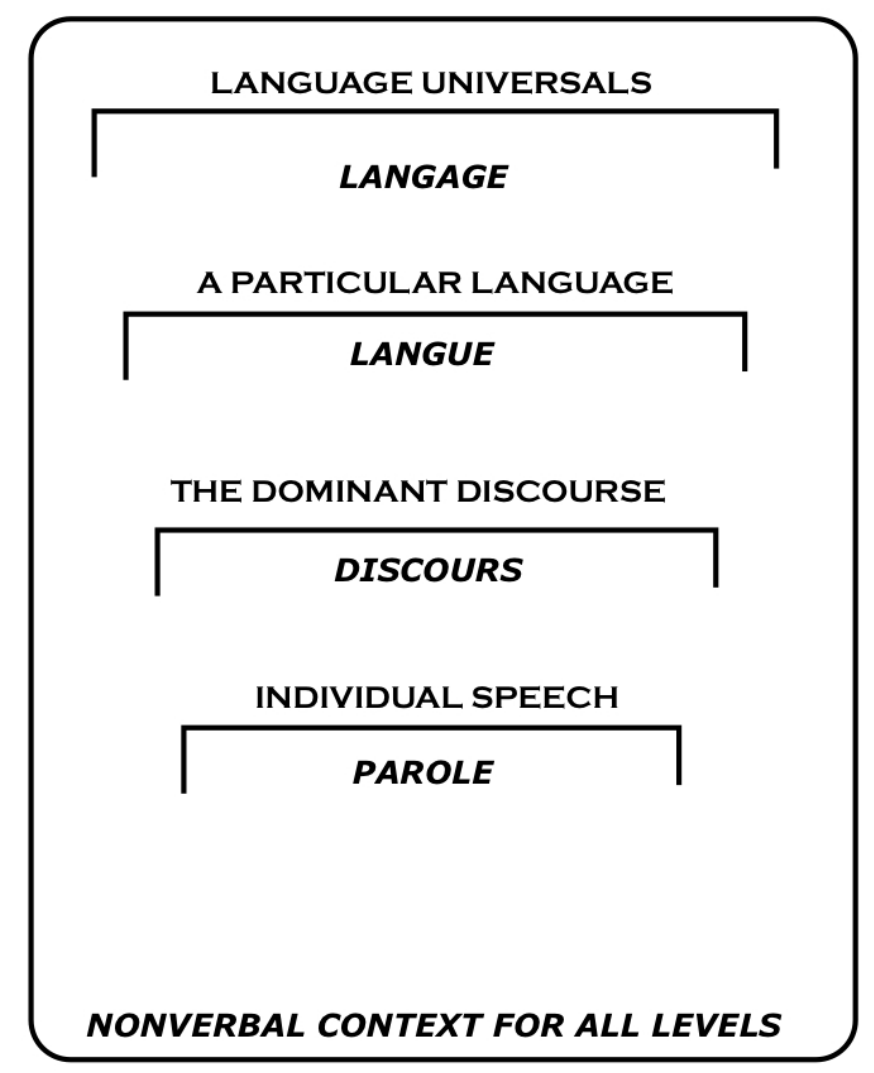

Figure 2. Discourse Hierarchy Model (Wilden 1980, 1987)

Utilizing the key discourse theories of Maurice Merleau-Ponty and Michel Foucault contextualized by the semiotic phenomenological work of Roman Jakobson, the discourse model can be elaborated as Fig. 3 . 


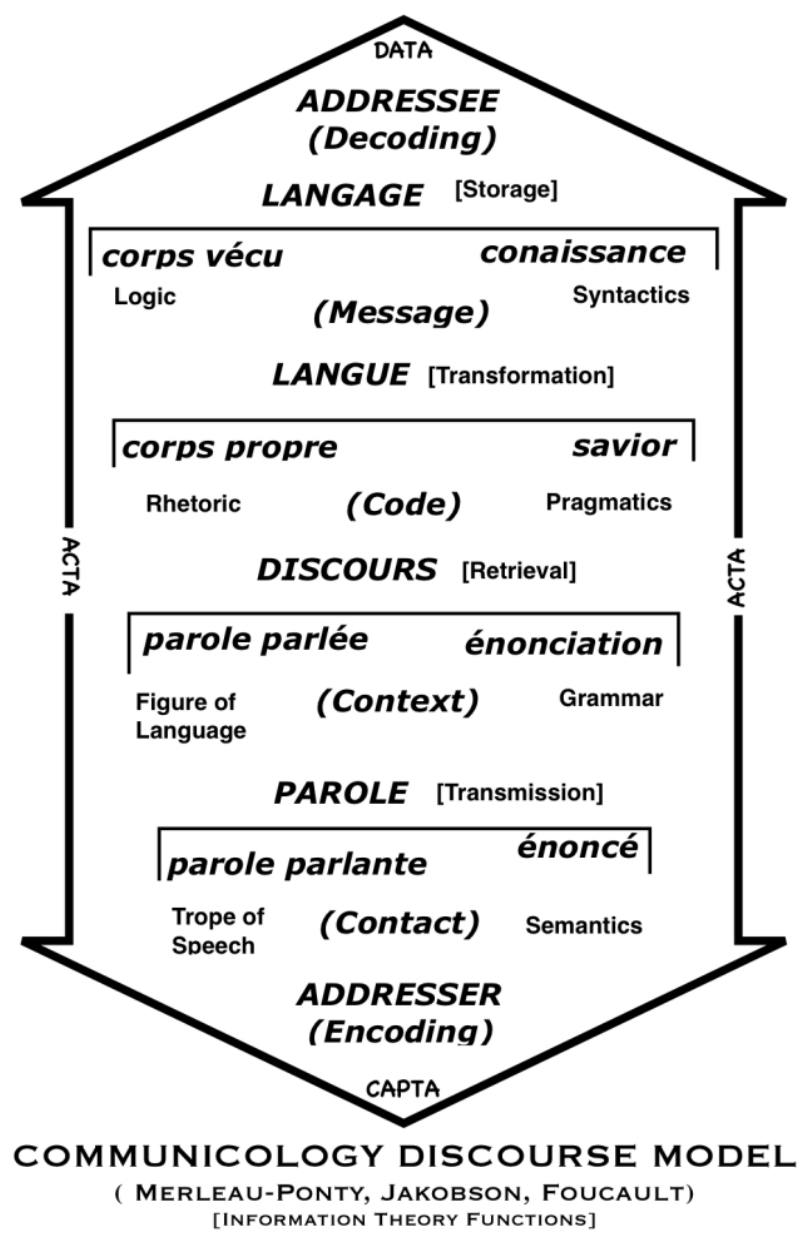

Figure 3. Communicology Model of Discourse Functions

The discourse elements specified in Fig. 3 are grounded philosophically in the phenomenological and semiotic tradition of philosophy and the human sciences, both American (Charles S. Peirce) and European (Roman Jakobson). Given the complexity of this metatheoretical approach, it will be useful to see the interdisciplinary convergence of logic, linguistics, semiotics, phenomenology, and communicology presented in Table 2. Basic categories are represented in the boxed concepts with the dialectic process relationships indicated by the given arrows linking boxes. Our particular concern is the ground for methodological comparisons that will be made later. For example, Syntactics and Pragmatics are Type 1 explanations where mechanical linkages are made in a language system, whereas Semantics and Sinegebung represents a Type 2 explanation where there is an isomorphism between language systems. Last, Chaism and "le Meme et L'Autre", are Type 3 explanations wherein there are transformations of the involved systems (Holenstein 1974: 7; see Table 4). 
In particular, Merleau-Ponty (1968: 263) uses the speech trope of chiasm and Bühler (1990: 438ff) gives a Type 3 explanation at the center of the discourse problematic and thematic with his discussion of anaphora deixis. Merleau-Ponty's example of chiasm is "I - Other - Other - I" and is the culmination of his semiotic phenomenology of discourse (1964: 86) which of course, informs Foucault formulation of his quadratic model of discourse usually formulated as “Self : Same :: Other : Different”(Lanigan 1992: 110).

Let me make special note of the discourse reference to Greek Cosmology that appears in Table 2. This to say in particular that Merleau-Ponty (as well as Martin Heidegger) makes subtle, but critical, reference to the Greek register of discourse. This fact is badly misunderstood by most readers of Merleau-Ponty when he makes such statements as "The world [nous] and reason [logos] are not problems; and though we might call them mysterious [mystos], this mystery [mythos] is essential to them: there can be no question of dissolving it [magikos] through some 'solution', it is beneath the level of solutions" (2012: 1xxxv; my insert). Or again, "In movement [mythos], the relationships [nous] between my decision [logos] and my body[mystos] are magic [magikos] ones" (2012: 97; my insert). Let me give the standard translations: logos (consciousness, rationality, speech that is), nous (mind) mystos (silence), mythos (speech that can be), magikos (art, technē). When the discourse sequence moves from logos $($ symbol $=$ present absence $)$ to magikos $($ symbol $=$ absent presence), we have the trope of speech called Asyndeton [voiceless name]; the reverse order is the trope of Prosopopeia [nameless voice]. Hence, the ambiguity of interpreting the prophesies of the Oracle at Delphi, especially when they are articulated as a chiasm! Last, let me emphasize that the very representational essence of a symbol is that it is per se a chiasm in communication. To explain, a symbol in discourse is simultaneously both encoded (nameless voice; prosopopoeia) and decoded (voiceless name; asyndeton) in the process of intersubjective communication - an empirical adductive proof of Husserl's proposition that “Subjectivity is Intersubjectivity”!(1969: 155; see Lanigan 2012). As Merleau-Ponty (2012: 474) confirms: "My life must have a sense that I do not constitute, there must be, literally an intersubjectivity; each of us must be at once anonymous in the sense of an absolute individuality and anonymous in the sense of an absolute generality. Our being in the world is the concrete bearer of this double anonymity." Hence, the synonymy of "communication" and "culture" in one word or symbol. 
Table 2. Comparative Table of the Human Sciences

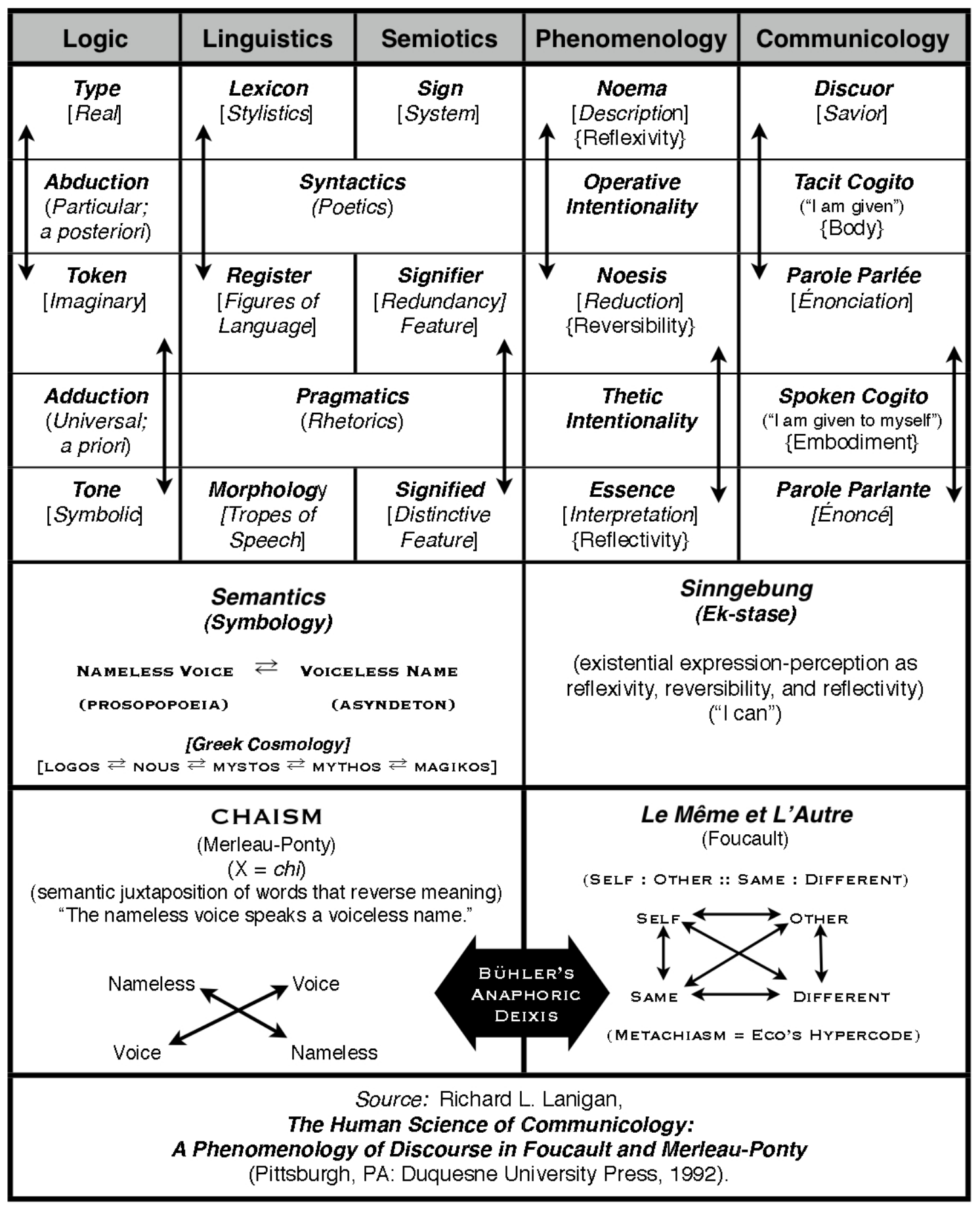




\section{Logic and Qualitative Research}

While is it generally known that quantitative research is based mainly on statistical formulations of occurrence frequency grounded in mathematics, it is also generally unknown that qualitative research is based on class typologies grounded in logic. While this fact may be intuitively obvious to philosophers generally and phenomenological philosophers in particular, it is scarcely acknowledged by phenomenological human scientists and generally unknown at all in the humanities disciplines. Note, however, that semiotics has stimulated research in Literary Science from the point of view that literature is discourse descriptive of human comportment in specific cultural contexts describing the Lebenswelt and Umwelt. Hence in Table 1, the connection among Stylistics, Poetics, and Rhetorics is a matter of phenomenological human science research. For example studies, see Lanigan (1984, 1995b, 2005). Hence, a brief review of the applicable logics in human science qualitative research is given in Table 3. The logics so discussed are part of the interface between theory and method, which is to say the dialectic of theory construction and methodological application as a test of theory.

The basic purpose of the Table 3 presentation is to provide a concise description of the basic logics available to human science research: Abduction, Adduction, Induction, and Deduction. In addition, we come to understand how the logics of abduction and adduction are applied as a logic of typology (type, token, tone) formulated by Peirce (Lanigan 1995a). For European phenomenologists it is also necessary make the correlation between these logics as used by Merleau-Ponty, Foucault, Husserl and the Peircian logic. The corresponding correlation to evidence $($ data $=$ what is given; $a c t a=$ what is done; capta $=$ what is taken $)$ as modalities of symbolism in discourse is an integral part of understanding the Lanigan approach to phenomenological method: (1) Thematizing the description of the Signs (system of understanding and memory), (2) Abstracting the description of the Signifier (expression), and (3) Explicating the the Signified (perception). The possible semiotic codes of phenomenological expression and perception are discussed at length in Lanigan (2010). 
Table 3. Theory and Methodology Logics

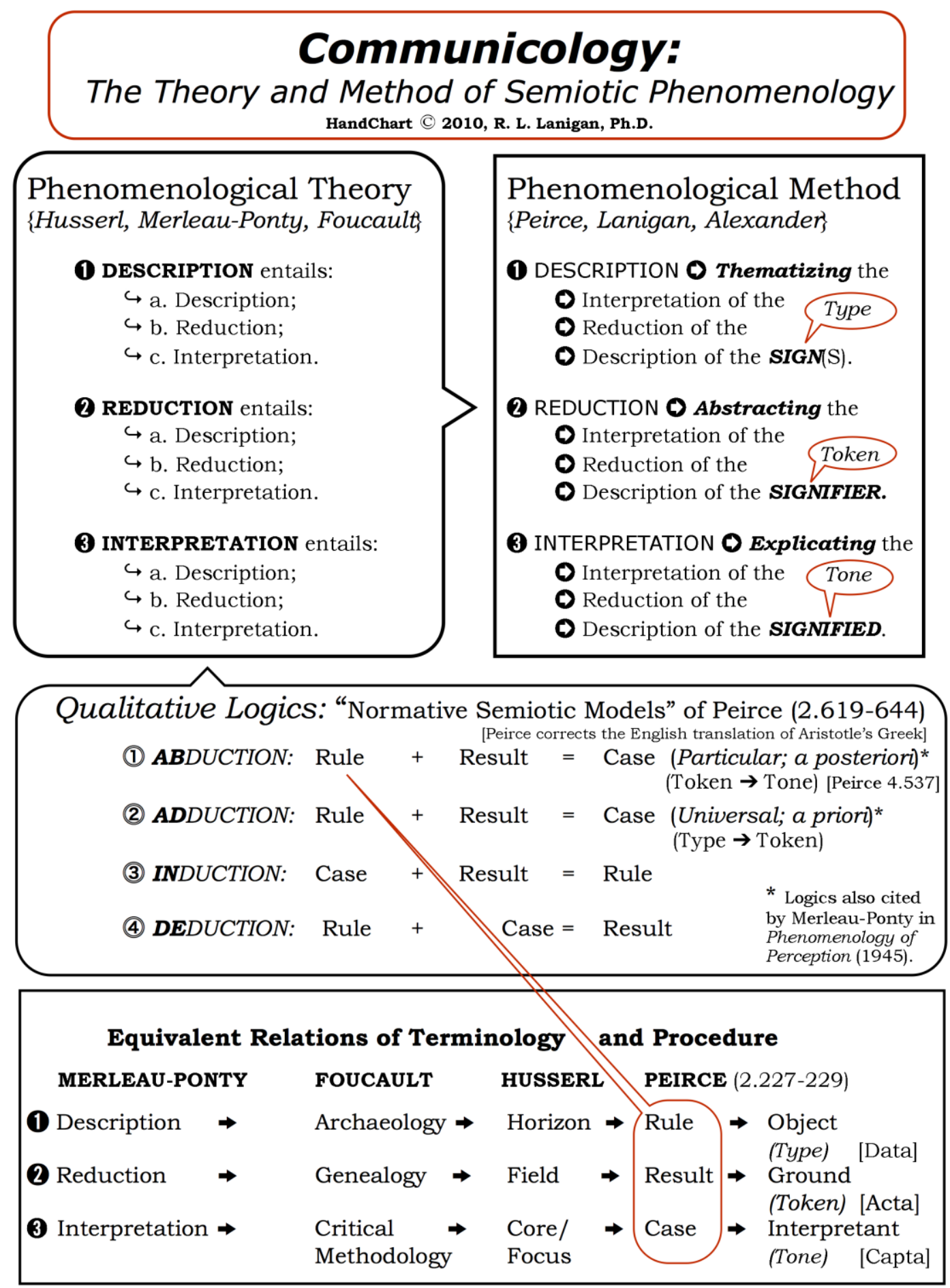




\section{Phenomenological Research}

In order to contextualize the Lanigan phenomenological methodology, Table 4 gives a brief comparison to the latest statement of method by Amedeo Giorgi, (2009), the leading phenomenological psychology researcher. The basic reason for the comparison is to emphasize the necessity of metatheory construction in phenomenology. In brief, Giorgi fails to adequately account for logic and linguistics as semiotic constituents of the phenomenological research situation. The result is a latent methodological positivism that is embedded in the "natural attitude" about language as the data given in interview based research. For example, Giorgi argues:

In fact, sentences are psychologically neutral in the sense that they could be psychologically loaded or empty. Sentences are not the primary way that psychological reality reveals itself in expressions. Of course, grammar of some type is necessary, but it is another dimension of expressiveness not well suited to reveal psychological meanings. Thus, the constitution of parts in the method are based upon the dimension that is most sensitive to the ultimate goal of the task.

Unfortunately, this is the same argument that analytic philosophers of language, like John Searle, use to say that eidetic "propositions"(noetic) are contained in empirical "sentences" (noema) and therefore grammar is not the operative logic in the analysis. There are two fundamental problems here:

(1) What language is the research using as an empirical actuality? If, for example, it is English, then English grammar dictates a very specific subject-predicate logic in analysis wherein typologies of meaning are pre-given [data] and it is impossible to distinguish between code signification (syntactics) and message meaning (semantics) as between speaker encoding (interviewee; research respondent) and listener decoding (interviewer; researcher) as referents in actuality (pragmatics). This is the confusion of parole parlée and parole parlante or énonciation and énocé, to cite only one the dimensional issues. Recall that coded symbols are representations on a minimum of two logical levels: the object language and the metalanguage. The minimum logic conditions for theory construction are three levels, i.e., Type 1, 2, and 3 semiotic explanations (Holenstein 1974: 7\}. 
Table 4. Methodology Comparison of Giorgi Descriptive Phenomenology and Lanigan Semiotic Phenomenology

\begin{tabular}{|c|c|c|}
\hline \multicolumn{3}{|c|}{ Human Science Phenomenological Method (Qualitative Research) } \\
\hline Metatheory & Giorgi Method & Lanigan Method \\
\hline Discipline & Psychology & Communicology \\
\hline Evidence & $\begin{array}{l}\text { Language Behavior, } \\
\text { Social Situation }\end{array}$ & $\begin{array}{l}\text { Speech, Body Comportment, } \\
\text { Lebenswelt, Umwelt }\end{array}$ \\
\hline Methodology & Experiential & Experiential, Experimental \\
\hline Evidence Collection & Transcribed Interviews & Human Discourse (all media) \\
\hline $\begin{array}{l}\text { Evidence Item } \\
\text { [Bordieu] }\end{array}$ & $\begin{array}{l}\text { "Meaning Unit" } \\
\text { [Habitus }]\end{array}$ & $\begin{array}{c}\text { "Revelatory Phrase / Image" } \\
\text { [Hexis] }\end{array}$ \\
\hline Data Theory & $\begin{array}{l}\text { Linguistic (uncritically assumed, } \\
\text { Grammar Neutrality dictates } \\
\text { Covert Epistemes) } \\
\text { Symbolization of Mental States }\end{array}$ & $\begin{array}{l}\text { Semiotic, Logic Symbolization } \\
\text { of Embodiment and } \\
\text { Intersubjective Practice }\end{array}$ \\
\hline Acta Theory & $\begin{array}{c}\text { Uncritical Identity of } \\
\text { Speech, Writing, and Thinking; } \\
\text { Social Context } \\
\text { (No Control for Bi-Cultural } \\
\text { Bi-Lingual, etc. Respondents) }\end{array}$ & $\begin{array}{c}\text { Differentiation of Symbolic } \\
\text { Comportment (all media); } \\
\text { Cultural Context } \\
\text { (culture, language controls) }\end{array}$ \\
\hline Capta Theory & $\begin{array}{c}\text { Information Theory: } \\
\text { Disjunctive Choice in Context } \\
\text { (Either/Or) }\end{array}$ & $\begin{array}{c}\text { Communication Theory: } \\
\text { Conjunctive Choice of Context } \\
\text { (Both/And) }\end{array}$ \\
\hline $\begin{array}{l}\text { Validity Criteria } \\
\quad=\text { Logic }\end{array}$ & $\begin{array}{l}\text { Inductive Logic, } \\
\text { Sufficient Condition }\end{array}$ & $\begin{array}{c}\text { Abductive and Adductive Logic, } \\
\text { Necessary Condition }\end{array}$ \\
\hline $\begin{array}{l}\text { Qualitative } \\
\text { Validity }\end{array}$ & $\begin{array}{c}\text { Intensional Semantic } \\
\text { Specification by Analytic Selection } \\
\text { of Paradigmatic Categories }\end{array}$ & $\begin{array}{c}\text { Extensional and Intensional } \\
\text { Specification by Analytic and Synthetic } \\
\text { Comparison of Paradigmatic and } \\
\text { Syntagmatic Categories } \\
\text { (Jakobson's "Prague Prism") }\end{array}$ \\
\hline $\begin{array}{l}\text { Reliability (Logical) } \\
\text { [Linguistic Systems] }\end{array}$ & $\begin{array}{c}\text { Replication } \\
\text { [Type 1 Explanation: Mechanical } \\
\text { linkage of single elements in a system] } \\
\text { [Assumption of Type } 2 \text { Explanation: } \\
\text { Isomorphism of the systems] }\end{array}$ & $\begin{array}{c}\text { Sufficient Condition } \\
{ }^{*}[\text { Type } 3 \text { Explanation: } \\
\text { Transformation of the systems] } \\
\text { [Bühler's Anaphoric Deixis] }\end{array}$ \\
\hline $\begin{array}{l}\text { Quantitative } \\
\text { Reliability }\end{array}$ & $\begin{array}{c}n 1+(\text { usually }<10) \\
\text { (until there is category redundancy) } \\
\{n 1+?=\text { Sufficient Condition }\}\end{array}$ & $\begin{array}{c}n 1 \\
\text { (Typology = Logical Class }) \\
\{n 1+1=\text { Necessary Condition }\}\end{array}$ \\
\hline $\begin{array}{l}\text { Metaphysics } \\
\text { (Husserf) }\end{array}$ & $\begin{array}{l}\text { Morphological Essence } \\
\text { of Behavior }\end{array}$ & $\begin{array}{l}\text { Morphological and Existential } \\
\text { Essence of Comportment }\end{array}$ \\
\hline Epistemology & $\begin{array}{l}\text { Analysis, then Synthesis; } \\
\text { Typology of Data } \\
\text { (NOT generalization) } \\
\text { [Theory Unknown] }\end{array}$ & $\begin{array}{c}\text { Comparative Analysis and Synthesis; } \\
\text { Type, Token, Tone Specification as } \\
\text { Typology of Capta } \\
\text { [Theory: Charles S. Peirce) }\end{array}$ \\
\hline
\end{tabular}


(2) Any dimension of "expressiveness" must be paired with a dimension of "perceptiveness" and this is impossible without an explicit statement of the semiotic system which constrains the conjunction of logic and linguistics as an analytic tool of application. This is, the limitation of expressiveness to "language" fails to account for the logical hierarchy of discourse (see Fig. 2). Which level of discourse is "psychological", "propositional", etc.?

Giorgi and Lanigan are in agreement about the metaphysical position from Edmund Husserl that grounds their phenomenological theory. In his early work, Husserl refers to what he labels "morphological essences". These are not the usual "transcendental essences" which seem to be, at best, difficult to specify. Even Husserl (1960; see Lanigan 2012) shifts toward the morphological category in his later work which is favored by most human scientists. Interestingly enough, neither Husserl nor Giorgi give a theoretical or applied account of what this metaphysical category of "morphology" means in the phenomenological method, except to say that such "essences" are not exact concept like those in mathematics, but are marked by "vagueness".

Let's try to sort this out the vagary by looking briefly at the linguistic concept of morphology (our research is based in discourse!), then we can move to the semiotic and logical equivalents. The Cambridge Encyclopedia of Language provides a standard account of morphology:

This branch of linguistics studies the structure of words. In the following list, all the words except the last can be divided into parts, each of which has some kind of independent meaning.

$\begin{array}{ll}\text { unhappiness } & \text { un- -happi--ness } \\ \text { horses } & \text { horse- -s } \\ \text { talking } & \text { talk- -ing } \\ \text { yes } & \text { yes }\end{array}$

Yes has no internal grammatical structure. We could analyze its constituent sounds, /j/, /e/, /s/, but none of these has any meaning in isolation. By contrast, horse, talk, and happy plainly have a meaning, as do the elements attached to them (the 'affixs'): un- carries a negative meaning; -ness expresses a state or quality; $-s$ expresses a plural; and -ing helps to convey a sense of duration. The 
smallest meaningful elements into which words can be analyzed are known as morphemes; and the way morphemes operate in language provides the subject matter of morphology (Crystal 1997: 90).

Considering the category of "Evidence Item" in Table 4, the importance of morphological essence becomes a critical point. For Giorgi, the "meaning unit" has no logical status in a typology until the researcher creates it, but on what theoretical basis? Here is where standard grammar provides a ready-made, natural attitude guideline. The result is a confirmation of grammar, not a phenomenological description of a mental state (psychology).

By contrast, Lanigan's "revelatory phrase" is guided by semiotic theory. Logic, especially abduction, requires a semiotics, namely, a sign-system that has two constitutive construction rules: (1) Things in the system, and, (2) Things outside the system. In the definition of morphology above, it is immediately obvious that Ihde has no guideline for explaining the "meaning unit" that counts as a morpheme. But using the "revelatory phrase" approach, semiotic theory immediately explains how morphemes are generated and how one type of morpheme (e.g., yes) can be distinguished from all others (Lanigan 2010a). Hence in our example, we have something like simple morphemes (e.g., yes) and complex morphemes (the other examples), i.e. two types and now the ability to differentiate typologies. This is precisely how linguists differentiate inflectional morphology (use of tone of voice to change meaning) from derived morphology (using compounds to form new token words, e.g. making drink into drinkable). For a theoretical account of the discourse semiotics applicable to our analysis, see my (1988: 223) "Semiotic Phenomenology in Plato's Sophist" which distinguishes the logic of grammar (genus-species) as "meaning unit" and the logic of semiotic (genus-differentia) in the "revelatory phrases" of discourse. An empirical example of the same issue is demonstrated using experimental phenomenology in "Guess at the Word, or, How to Phenomenologically research the hermeneutic Experience of Language and Logic" (Lanigan 1988: 118). An explicit comparison to Giorgi's method is my text based study of one "revelatory phrase" $(\mathrm{n}=1)$ in "Metajournalism: Merleau-Ponty on Signs, Emblems, and Appeals in the Poetry of Truth" (Lanigan 1988: 103; for an analysis of a single word and coding at the phonological level, see2010a). 


\section{Understanding Culture and Communication}

Where does the analysis stand at this point? We began with Don Ihde's phenomenological attempt to extend philosophical analysis from the eidetic level to the empirical level by means of a "thought experiment" transformed to an "experience experiment". Of course experiential research (in contrast to the statistical projection of eidetic categories represented as "behavior") is fundamentally empirical because it is concrete, actual experience, not the idea of experience which is hypostatized as real (Ihde) or as ideal (Searle's "conceptual realism"). Then, we moved to Amedeo Giorgi's latest theoretical discussion of empirical phenomenological method to account for experiential research. I found theoretical problems with this method and illustrated my alternative method and its metatheoretical (interdisciplinary) ground in Table 4.

I now want to turn to the experimental communication research of Tom McFeat because he uses an experiential phenomenological method of communication analysis to accomplish these ground breaking results: (1) an account of how communication constitutes culture by means of intergenerational communication, and hence, (2) how group culture as a communication medium constitutes the formation of understanding and memory for individual persons. To understand communication among generations of people, we will briefly review the work of Margaret Mead based on her anthropological research in various cultural settings.

\subsection{Mead on Generational Communicology}

Understanding human values in families, how they are remembered and then passed from one generation to another is an enduring question for those who study human culture. In modern times with modern technology, the study of long-term transmission of messages has become critical. For example, the necessity of marking nuclear waste sites with "danger" warning messages that will endure and be understood after 10,000 years or 100 generations is a current practical problem being researched in the USA (Lanigan 1995c; Sebeok 1982).As a brief introduction to the semiotic system codes involved with intergenerational communication, Table 5 give a summary of Mead's model of generational communication as a cultural paradigm. 
Table 5. Margaret Mead's Model of Intergenerational Communicology

\begin{tabular}{|c|c|c|c|}
\hline \multicolumn{4}{|c|}{$\begin{array}{l}\text { MARGARET MEAD'S MODEL OF CULTURAL COMMUNICOLOGY } \\
\text { (SEMIOTIC INNOVATION, TRANSMISSION, STORAGE, RETRIEVAL) } \\
\text { The continuity and survival of all cultures require the living presence } \\
\text { of at least three generations who engage in group communication. }\end{array}$} \\
\hline $\begin{array}{l}\text { CULTURE } \\
\text { TYPOLOGY }\end{array}$ & $\begin{array}{l}\text { POSTFIGURATIVE } \\
\text { TOKEN CULTURE }\end{array}$ & $\begin{array}{l}\text { COFIGURATIVE } \\
\text { TOKEN CULTURE }\end{array}$ & $\begin{array}{l}\text { PREFIGURATIVE } \\
\text { TOKEN CULTURE }\end{array}$ \\
\hline $\begin{array}{l}\text { Developmental } \\
\text { Process (TONE) }\end{array}$ & $\begin{array}{c}1 \mathrm{st} \text { GENERATION } \rightarrow \\
\langle\text { GRANDPARENTS }>\end{array}$ & $2^{\text {nd }} \underset{\text { GeNERATION }}{\text { GPARENTS }>}$ & $\begin{array}{c}3^{\text {rd }} \text { GENERATION } \\
\langle\text { CHILDREN }\rangle\end{array}$ \\
\hline $\begin{array}{l}\text { LOGIC } \\
\text { CODE }\end{array}$ & $\begin{array}{l}\text { Children learn primary } \\
\text { from FOREBEARS } \\
\text { (Old Forms } \\
\text { ASSIMILATE } \\
\text { New Forms) }\end{array}$ & $\begin{array}{l}\text { Children and Adults learn } \\
\text { from their PEERS } \\
\text { (Old Forms } \\
\text { ACCOMMODATE } \\
\text { New Forms) }\end{array}$ & $\begin{array}{l}\text { Adults learn from } \\
\text { their CHILDREN } \\
\text { (New Forms } \\
\text { ASSIMILATE } \\
\text { Old Forms) }\end{array}$ \\
\hline $\begin{array}{c}\text { CHRONEMIC } \\
\text { CODE }\end{array}$ & $\begin{array}{l}\text { Reality is the } \\
\text { PAST. } \\
\text { Elders cannot conceive } \\
\text { of change. }\end{array}$ & $\begin{array}{l}\text { Reality is the PRESENT. } \\
\text { Difference and Change is } \\
\text { a normal expectation. }\end{array}$ & $\begin{array}{l}\text { Reality is the } \\
\text { FUTURE. } \\
\text { The new and unexpected } \\
\text { is a normal expectation. }\end{array}$ \\
\hline $\begin{array}{l}\text { PROXEMIC } \\
\text { CODE }\end{array}$ & $\begin{array}{l}\text { Each Person is an } \\
\text { Embodiment } \\
\text { of the Whole Culture. }\end{array}$ & $\begin{array}{l}\text { Postfigurative Culture } \\
\text { begins to breakdown; } \\
\text { Embodiment is not } \\
\text { predictable (Entropy). }\end{array}$ & $\begin{array}{l}\text { Cofigurative Culture } \\
\text { begins to breakdown; } \\
\text { Children embody the new } \\
\text { culture (Negentropy). }\end{array}$ \\
\hline $\begin{array}{l}\text { KINESIC } \\
\text { CODE }\end{array}$ & $\begin{array}{l}\text { Migration is Internal; } \\
\text { geographical within } \\
\text { regional boundaries. }\end{array}$ & $\begin{array}{l}\text { Migration is External; } \\
\text { geographical across } \\
\text { national boundaries. }\end{array}$ & $\begin{array}{l}\text { Migration is Internal; } \\
\text { Economic across class } \\
\text { boundaries. }\end{array}$ \\
\hline $\begin{array}{l}\text { HAPTIC } \\
\text { CODE }\end{array}$ & $\begin{array}{l}\text { Gender Roles are } \\
\text { Stereotypical; } \\
\text { Embodiment is } \\
\text { Iconic }\end{array}$ & $\begin{array}{l}\text { Gender Roles are } \\
\text { Prototypical; } \\
\text { Embodiment is } \\
\text { Indexical }\end{array}$ & $\begin{array}{l}\text { Gender Roles are } \\
\text { Atypical; } \\
\text { Embodiment is } \\
\text { Symbolic }\end{array}$ \\
\hline $\begin{array}{l}\text { LiNGUISTIC } \\
\text { CODE }\end{array}$ & $\begin{array}{l}\text { All three generations are } \\
\text { Monolingual } \\
\text { and } \\
\text { Mono-gestural }\end{array}$ & $\begin{array}{l}\text { One generation is } \\
\text { monolingual; one or two } \\
\text { generations are partially } \\
\text { Bilingual - Bi-gestural. }\end{array}$ & $\begin{array}{l}\text { Children can be fully } \\
\text { Bilingual and } \\
\text { Bi-gestural, hence } \\
\text { Bi-Cultural. }\end{array}$ \\
\hline $\begin{array}{l}\text { COMMUNICATION } \\
\text { CODE }\end{array}$ & $\begin{array}{l}\text { All verbal and nonverbal } \\
\text { forms are SYNTHETIC } \\
\text { (Oral Tradition } \\
\text { dominates the } \\
\text { Written Tradition; } \\
\text { Fashion and Dress } \\
\text { are Stereotypical) }\end{array}$ & $\begin{array}{l}\text { All verbal and nonverbal } \\
\text { forms are INFERENTIAL } \\
\text { (Nonverbal } \\
\text { Fashion and Dress } \\
\text { choice dominates; } \\
\text { verbal critique is } \\
\text { ignored) }\end{array}$ & $\begin{array}{l}\text { All verbal and nonverbal } \\
\text { forms are ANALYTIC } \\
\text { (Technology Innovation } \\
\text { dominates verbal } \\
\text { practices; nonverbal } \\
\text { norms are ambiguous } \\
\text { and experimental) }\end{array}$ \\
\hline \multicolumn{4}{|c|}{$\begin{array}{l}\text { Table is based on: } \\
\text { Margaret Mead, Culture and Commitment: A Study of the Generation Gap } \\
\text { (Garden City, N: Doubleday \& Co., Inc. 1970) } \\
\text { Richard L. Lanigan, The Human Science of Communicology } \\
\text { (Pittsburgh, PA: Duquesne University Press, 1992). }\end{array}$} \\
\hline
\end{tabular}

\subsection{McFeat's Small Group Experimental Phenomenology}

Tom McFeat (1974, 1979, 2002) was a doctoral student of Robert Bales in the Department of Human Relations at Harvard University and spent his career teaching anthropology at the University of Toronto, Canada. He did extensive field research on the 
Navajo and Zuni cultures in Arizona and New Mexico (USA) in addition to the Northwest Indians of Canada. I was privileged to have attended his seminar in Toronto (Lanigan 1980; see Lanigan 2012b). Robert Bales' classic research on small group communication is the base from which McFeat created his experimental model for culture generation. For a discussion of the classic model of task group and affiliation group formation and communication structure, see Lanigan (2011a,b).

Recalling Figs. 2 and 3, we must first examine the discourse context assumed by McFeat in developing his research experiment. This is to say, human scientists surmise that successful intergenerational communication beyond ten generations (1000 years) requires the use of a myth discourse model (see Lanigan 1995c, Sebeok 1982). Recalling the Greek Cosmology of Discourse in Table 1, the consensus means that the successful discourse system must reach the mythos and magikos level for successful understanding and preservation in memory(coding) of a critical message in culture. Table $\mathbf{6}$ is a summary of these ideas including McFeats information content categories.

This use of myth discourse is easier to comprehend, if I put it this way: a message must be internalized in the mind as a meaning critical for survival and the memory will be aided by embodiment practices (rituals) that stimulate this memory. In most cultures this discourse myth-ritual phenomenon is easily recognized as "praying to god for understanding in moments that threaten survival". I have previously used the myth model, derived from the work of Claude Lévi-Strauss (1958: 202-228), to analyze schizophrenic discourse in a therapy situation (Lanigan 2010a) and in a novel (Lanigan 2005). All such research must take account of the eidetic and empirical complexity of reference when embodied as discourse, either verbal (Lanigan2010b) or nonverbal (Lanigan 2012). Recall from Table 1 that a normal discourse paradigm describes Actuality by (1) matching diachronic time with syntagmatic space and (2) matching synchronic time with paradigmatic space; culture calls this Reality. This is the Greek metaphysical model wherein discourse contextualizes ritual in the sequence $[\log$ os $\rightarrow$ nous $\rightarrow$ mystos $\rightarrow$ mythos $\rightarrow$ magikos]. In short, "saying" leads to "doing". 
Table 6. Discourse Model Correlation to Myth Hermeneutics

\begin{tabular}{|c|c|c|c|}
\hline 1. Information & Example & 2. Comunication & 3. Communicology \\
\hline $\begin{array}{l}\text { 1. Content-Ordered } \\
\text { Culture }\end{array}$ & $\begin{array}{c}\text { Narrative } \\
\{\text { Hermeneutic\} }\end{array}$ & $\begin{array}{l}\text { 2. Task-Ordered } \\
\text { Culture }\end{array}$ & $\begin{array}{l}\text { 3. Group-Ordered } \\
\text { Culture }\end{array}$ \\
\hline $\begin{array}{l}\text { 1. Postfigurative } \\
\text { Culture }^{\star}\end{array}$ & $\begin{array}{l}\text { Figuration = } \\
\text { matrix pattern }\end{array}$ & $\begin{array}{l}\text { 2. Cofigurative } \\
\text { Culture }^{*}\end{array}$ & $\begin{array}{l}\text { 3. Prefigurative } \\
\text { Culture }^{*}\end{array}$ \\
\hline $\begin{array}{l}\text { a Children learn primarily } \\
\text { from their forebearers. } \\
\text { b. Elders cannot conceive } \\
\text { of change; reality is the } \\
\text { Past. } \\
\text { c. Continuity reflects itself } \\
\text { in synthetic forms of } \\
\text { speech and gesture. }\end{array}$ & $\begin{array}{l}\text { *Margaret Mead (1970): } \\
\text { The continuity and survival } \\
\text { of all cultures requires the } \\
\text { Iiving presence of at least } \\
\text { three generations who en- } \\
\text { gage in group communica- } \\
\text { tion. }\end{array}$ & $\begin{array}{l}\text { a Children and Adults learn from } \\
\text { their peers. } \\
\text { b. Difference and change is a } \\
\text { normal expectation; reality is the } \\
\text { Present. } \\
\text { c. Continuity is linked to fashion } \\
\text { and dress; sexual roles are } \\
\text { stereotypic and symbolic. }\end{array}$ & $\begin{array}{l}\text { a. Adults learn from their } \\
\text { Children. } \\
\text { b. The new, unexpected are } \\
\text { normal; reality is the Future. } \\
\text { c. Continuity is linked to im- } \\
\text { mediacy of experience, medi- } \\
\text { ated by technology. }\end{array}$ \\
\hline $\begin{array}{l}\text { Referent Content } \\
\text { Culture is an } \\
\text { organization in Space. }\end{array}$ & $\begin{array}{l}\text { Myth Level } 0 \\
\{\text { Literal }\} \\
\text { *־Tom McFeat (1974): } \\
\text { Experimental Group } \\
\text { Phenomenology }\end{array}$ & $\begin{array}{c}\text { Langage } \\
\{\text { Logic, Syntactics }\} \\
\text { Culture is an organization } \\
\text { in Space. }\end{array}$ & $\begin{array}{c}\text { Actuality }= \\
\text { Concrete Experience } \\
\text { Culture is an organization } \\
\text { in Space. }\end{array}$ \\
\hline $\begin{array}{l}\text { Basic Content } \\
\text { Culture is a static } \\
\text { pattern of action in } \\
\text { Time. }\end{array}$ & $\begin{array}{c}\text { Myth Level } 1 \\
\{\text { Allegorical }\} \\
\\
\text { The First Half Novel } \\
\text { (Given Facts = Data) } \\
\text { "depicting the characters } \\
\text { and events as given" } \\
\text { (p. 129) }\end{array}$ & $\begin{array}{l}\text { Langue } \\
\text { \{Rhetoric, Pragmatics\} } \\
\text { Culture is a dynamic pattern } \\
\text { of interaction in Time. }\end{array}$ & $\begin{array}{c}\text { Reality }= \\
\text { Abstract Experience } \\
\text { Culture is a dynamic } \\
\text { matrix of transaction } \\
\text { in Time. }\end{array}$ \\
\hline $\begin{array}{l}\text { Interpreted Content } \\
\text { Information (messages) } \\
\text { remains stable. }\end{array}$ & $\begin{array}{l}\text { Myth Level } 2 \\
\quad \text { \{Tropological\} } \\
\text { "This intermediate form } \\
\text { was sought after in all } \\
\text { groups before they were } \\
\text { willing to or even able to } \\
\text { innovate. This became a } \\
\text { commentary on the novel } \\
\text { but also a means of refer- } \\
\text { ring to conditions arising } \\
\text { outside this novel or novels } \\
\text { in general" (p. 129) }\end{array}$ & $\begin{array}{c}\text { Discours } \\
\text { \{Figure of Language; } \\
\text { Grammar\} } \\
\\
\text { Information (context) is } \\
\text { unstable; environmental } \\
\text { pressure to change. }\end{array}$ & $\begin{array}{c}\text { Ideality = } \\
\text { Consciousness of Ex- } \\
\text { perience } \\
\text { Information is shared } \\
\text { meanings }(\text { codes } \text { in the } \\
\text { group as a concrete } \\
\text { medium. }\end{array}$ \\
\hline $\begin{array}{l}\text { Innovated Content } \\
\text { The group is unaffected } \\
\text { by the inflow of } \\
\text { information. }\end{array}$ & $\begin{array}{c}\text { Myth Level } 3 \\
\text { \{Anagogical\} } \\
\text { The [missing] Second } \\
\text { Half Novel } \\
\text { (Taken Facts = Capta) } \\
\text { "the conclusion sought } \\
\text { after or arrived at" } \\
\text { (p. 129) }\end{array}$ & $\begin{array}{l}\text { Parole } \\
\text { \{Trope of Speech; } \\
\text { Semantics\} } \\
\text { The group is fundamentally } \\
\text { affected by the inflow of in- } \\
\text { formation (context); there is } \\
\text { a potential for restructuring } \\
\text { the group. }\end{array}$ & $\begin{array}{l}\text { Surreality = } \\
\text { Experience of } \\
\text { Consciousness } \\
\text { The group is fundamentally } \\
\text { affected by the inflow } \\
\text { and outflow of informa- } \\
\text { tion (contact); theres is an } \\
\text { actual and ongoing struc- } \\
\text { turing of the group. }\end{array}$ \\
\hline
\end{tabular}

The analysis of an abnormal discourse paradigm (e.g., schizophrenia, religious conversion, etc.) takes Actuality and constructs a Myth or Ideality by (1) matching diachronic time with paradigmatic space and (2) matching synchronic time with syntagmatic space; culture calls this ideal construction Myth. This construction reverses the Greek metaphysical model such that ritual contextualizes discourse in the sequence [magikos $\rightarrow$ mythos $\rightarrow$ mystos $\rightarrow$ nous $\rightarrow$ logos]. Thus, "doing" precedes "saying". Thus, the western aphorism of "Do as I say, not as I do" is meant to promote the myth of culturally appropriate decisions. Table 7 allows for a comparison of the paradigmatic function in both "real" and "myth" discourse. Lévi-Strauss (1958: 202-228) worked closely with Roman Jakobson(1962-2000) at 
the New School for Social Research in New York City, thus the shared fundamental elements of structural linguistics in both scholars approach to cultural discourse.

Table 7. Lanigan Reality/Myth Model based on Jakobson and Lévi-Strauss.

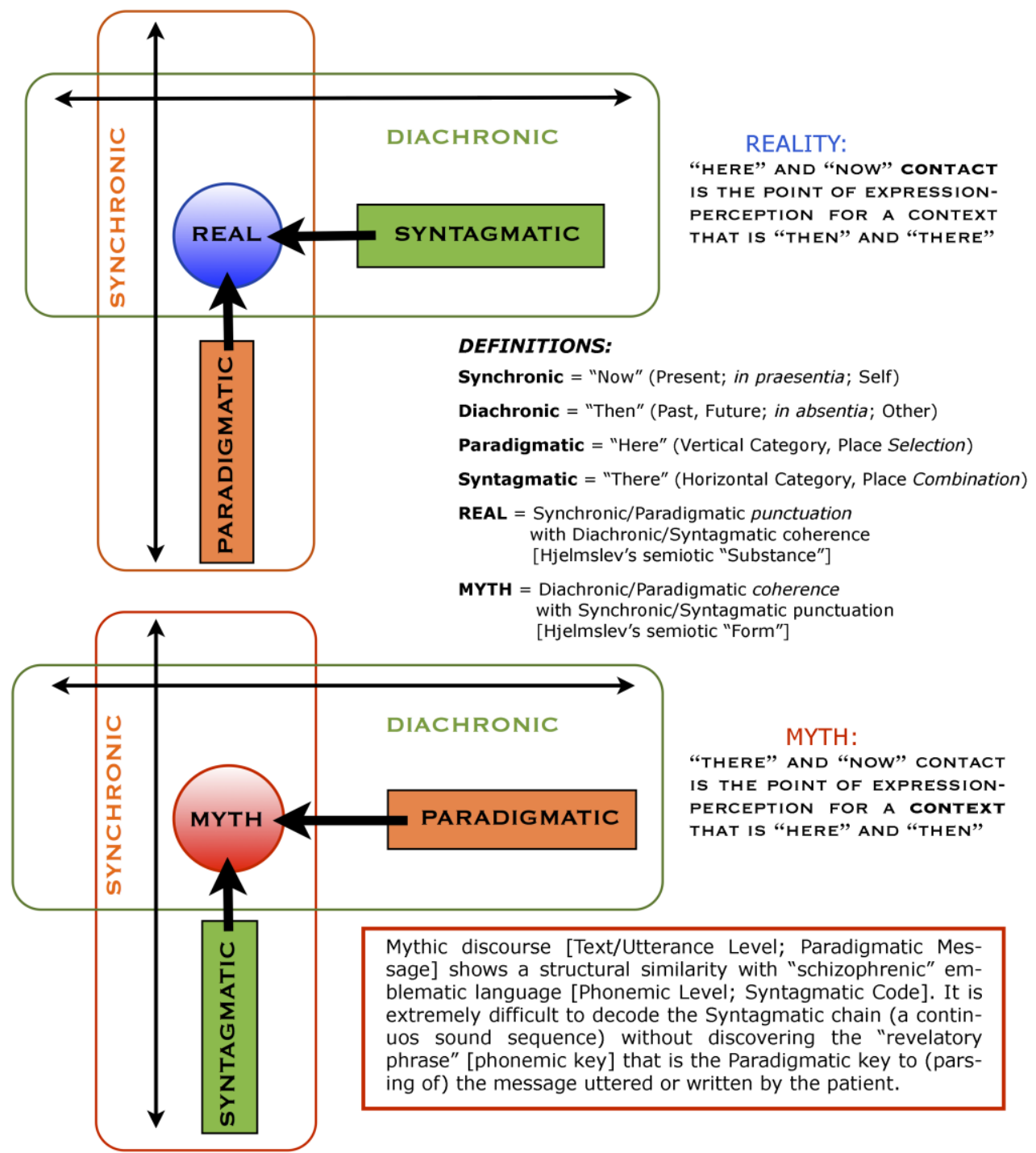

The basic research problematic that McFeat proposes to investigate is the fact that each generation of a group (e.g., a family) selects a referent content of information (formation) as it's understanding of their Lebenswelt situated in an Umwelt. When a second generation emerges (birth of children), the information (message/code) is passed along to the new generation. The resulting dialogue between the two generations involves dialogue about the morphological essence of the content resulting in the transformation of the content so that it becomes interpreted content information. From a phenomenological perspective the 
formation of referent content is a phenomenological description. Using Lanigan's method (see Table 3), this is a first generation "thematizing the signs" followed by a second generation "abstracting of the signifiers" (confirmed by the first generation), i.e., performing a phenomenological reduction. With the introduction of a third generation (grandchildren), the communication process continues with the interpreted content transforming to become innovated content information. Innovated information is now the accepted actuality referent information now known as Reality (the information has been phenomenologically verified as reliable).

In all of McFeats 1967 experimental groups, at least six (6) generations occurs successfully. The importance of achieving the six generation mark is that it verifies the full implementation of the all the recursive steps (both theoretical and methodological) of the Lanigan method (again see Table 3). Keep in mind that Step 9 in method is a dialectic shift of transformation back into Step 1 from the perspective of the succeeding generation. The failure of McFeat's 1966 and 1970 group experiments confirms the necessity of Mead's abduction that three generations are minimally required for the formation and survival of cultural information.

McFeat's three experiential group experiments are summarized in Table 8 for easy comparison of success and failure features. He experiments with three different conditions of textual message: (1) a magazine article [complete narrative text], (2) an incomplete fiction book \{ a novel with the final chapter missing = no conclusion], and (3) memory, i.e., an ideal text [a narrative story assumed in experiential memory]. It may not be apparent at first, but text (1) was "real" in that it was content ordered as "what was read" and then existed in memory as reality, but was actually not available for reading by the second and subsequent generations who had only a "lost text". In the case of text (3), no actual text ever existed, but narrative memory of experience was transformed into a "real text" as if some actual texts could be referenced in some vague sense of "everyone knows it". Text (2) is an "actual text" completed by the first generation as an "actual text made into real text" \{narrative end invented according to cultural values in the group] that the second generation has to interpret as a complete "real text", and then the "real text" was innovated by the third generation as the "ideal text" or myth.

Now we may draw some conclusions about experiential phenomenological method as used by groups as a medium to communicate their understandings as culture. The 1966 group is an example of text (1) and is precisely the type of process that Giorgi's method represents. The 1970 group is an example of text (3) and matches the propositional assumption of speech 
act theorists like John Searle. Neither of the methodological approaches produce an understanding of either communication or culture as the basis for human understanding and memory. The message representations as "real" and "ideal" cannot be specified as "actual" in communicative or cultural experience, much less the "consciousness of" them. Text (2) is an "actual" message that can be communicated as "real" and culturally preserved (in memory) as "ideal" thereby constituting understanding.

A final word needs to be said about McFeat's surprise and mild confusion by the communicative comportment of Lin's Group in the 1967 experiments. The short explanation, contained in Table 9, is that McFeat was unaware of the communicological differentiation of cultures on the basis of preferred communication semiotic structures (codes) at the intergroup level. As a researcher with an Egocentric culture model of perception, he was literally unable to perceive the Sociocentric modality of expression produced by his Hong Kong students within their Chinese cultural framework. For an example studies illustrating these egocentric and sociocentric differences, see Lanigan (2011b, 2012b) or Roberts (1951).

Western cultures in general, and the USA and Canada in particular, are Egocentric cultures favoring individual direct communication where individual leadership is favored over membership participation. By comparison, Eastern Cultures and the Chinese in particular are sociocentric cultures that prefer indirect communication in a group. There is a preferred deference to group opinion where membership participation is prized above leadership; unique individual behavior is avoided (Lanigan 2009, 2012c). Sociocentric cultures actually have an advantage when it comes to intergenerational communication inasmuch as they promote a narrative structure that favors consistency of memory over time for most messages meant to endure for many generations. Hence, references to ancestors in China is ubiquitous, while similar references to forebearers in the USA are rare indeed! 
Table 8. McFeats Experimental Phenomenology for 1966, 1967 (3 Groups), 1970

\begin{tabular}{|c|c|c|}
\hline \multicolumn{3}{|c|}{ Small Group Culture Structure } \\
\hline GROUP & & INSTRUCTION \\
\hline $\begin{array}{l}1966 \text { Group } \\
\text { Generation Turn-Over Principle: } \\
\text { "If information content proved to be } \\
\text { teachable and learnable then (a) } \\
\text { the group would continue; when } \\
\text { the teaching and learning were } \\
\text { complete, then (b) new members } \\
\text { would be introduced who (c) would } \\
\text { learn what had been taught in such } \\
\text { a way that (a) all members would } \\
\text { also teach what was to be learned. } \\
\text { This design was learned several } \\
\text { thousand years ago with the intro- } \\
\text { duction into the human community } \\
\text { of narrative style which in turn } \\
\text { evolved into myths" (p. 116). }\end{array}$ & $\begin{array}{l}\text { MAGAZINE ARTICLE } \\
\text { "What Has Happened to Our Old- } \\
\text { Fashioned Morals" Ladies Home } \\
\text { Journal December } 1961 \\
\text { 1. Read by First Generation. } \\
\text { 2. Only Oral Transmission to Sec- } \\
\text { ond Generation. } \\
\text { 3. Transmit information to next } \\
\text { generation. } \\
\text { "We looked for a single and con- } \\
\text { tinuous problem which resolved } \\
\text { itself into action that was not ter- } \\
\text { minal. The solution to such a prob- } \\
\text { lem should (a) perpetuate a group, } \\
\text { (b) introduce new members, (C) } \\
\text { train all members in such a way as } \\
\text { to (a) perpetuate the group. And } \\
\text { so on." (p. 115) }\end{array}$ & $\begin{array}{l}\text { "Without benefit of further reading, } \\
\text { please agree among yourselves about } \\
\text { the content of this article and then be } \\
\text { prepared to pass this on as new } \\
\text { members enter the group to replace } \\
\text { established members, when you feel } \\
\text { you are ready to receive them. Please } \\
\text { bear in mind that only you will have } \\
\text { red the article." }\end{array}$ \\
\hline \multicolumn{3}{|c|}{$\begin{array}{l}1966 \text { Group Culture Failure Characteristics: Members assumed the identity of the five personalities men- } \\
\text { tioned in the article; one also became the moderator. Real and fictive roles merged creating constant humor. The } \\
\text { grouped became closed. Content was structured in the sequence of the article presentation; a moderator as- } \\
\text { signed topics; new members were given sub-topics, but not coordinated. Transition to generations did not occur. } \\
\text { "Although our cases are few, the evidence is suggestive that the failure of the } 1966 \text { and the success of the } 1967 \\
\text { groups are in part understandable in terms of the stringencies and utilities of conditions set up by the different con- } \\
\text { tent structures (or codes) confronting initial groups" (p. 127). }\end{array}$} \\
\hline $\begin{array}{l}1967 \text { Groups } \\
\text { \{3 Successful Groups\} } \\
\text { "We seek to discover how estab- } \\
\text { lished myths perpetuate in a small- } \\
\text { group medium. Myth not only lends } \\
\text { itself to transmission in groups but } \\
\text { maintains its integrity across gen- } \\
\text { erations. But how?" (p. 127) } \\
\text { "New members entered all groups } \\
\text { within two to four weeks of forma- } \\
\text { tion; and again within a week after } \\
\text { joining, they showed evidence of } \\
\text { being familiar with the contents of } \\
\text { information" (p. 129). }\end{array}$ & $\begin{array}{l}\text { NOVEL } \\
\text { "We decided to introduce a novel } \\
\text { (actually a half-novel) into the } \\
1967 \text { groups where this had not } \\
\text { been done the previous year. ... } \\
\text { The novel we introduced was writ- } \\
\text { ten by Frances Shelley Wees, a } \\
\text { Canadian writer of great experi- } \\
\text { ence and skill; written in 1956, it } \\
\text { was entitled The Keys of My } \\
\text { Prison" (p. 127). }\end{array}$ & $\begin{array}{l}\text { Suggest a conclusion (the missing } \\
\text { second half of the novel) to the narra- } \\
\text { tive. "The [narrative] themes center on } \\
\text { these questions: 'Can a woman ever } \\
\text { really know the man she married? } \\
\text { Can family solidarity hold out against } \\
\text { intrusion through seduction? What } \\
\text { brings on, what cures, and what is } \\
\text { revealed in amnesia? When troubled, } \\
\text { does one turn to the establishment?' ' } \\
\text { (p. 128). }\end{array}$ \\
\hline
\end{tabular}


Table 8. (continued vertically, part 2)

\begin{tabular}{|c|c|c|}
\hline \multicolumn{3}{|c|}{ Small Group Culture Structure } \\
\hline GROUP & & INSTRUCTION \\
\hline $\begin{array}{c}\text { BUSTER'S GROUP } \\
\text { [Western Heritage } \\
\text { Canadians; } \\
\text { Egocentric Group] }{ }^{\star}\end{array}$ & $\begin{array}{l}\text { Each group member became a } \\
\text { character in the novel: Robin } \\
\text { Sloan (lawyer), Dr. Prescott, Dr. } \\
\text { Merrill, P. C. Lake (police), Aunt } \\
\text { Edie, her niece, Julie (central fig- } \\
\text { ure), and Rafe (Julie's husband). } \\
\text { "There was a tendency for new } \\
\text { members to direct inquires and } \\
\text { requests for clarification to first- or } \\
\text { second-generation mem bers } \\
\text { since, from their point of view, } \\
\text { there was no difference between } \\
\text { them" (p. 133). }\end{array}$ & $\begin{array}{l}\text { Moved through Six Generations. } \\
\text { "First and Second generations argued } \\
\text { from a symmetrical (same level) } \\
\text { rather than a complementary (genera- } \\
\text { tion one vs. Generation two) basis" (p. } \\
\text { 131). } \\
\text { "Literal information retrieval occurred } \\
\text { in narrative: one person was chosen } \\
\text { to narrate and others corrected details } \\
\text { when necessary" (p. 133). } \\
\text { "Buster's group operated with three } \\
\text { generations and then moved to a no- } \\
\text { generation pattern when innovating" } \\
\text { (p. 139). }\end{array}$ \\
\hline $\begin{array}{c}\text { CRANSHAW'S GROUP } \\
\text { [Western Heritage } \\
\text { Canadians; } \\
\text { Egocentric Group] }{ }^{\star}\end{array}$ & $\begin{array}{l}\text { "Specifics of content passed } \\
\text { through many generations, indeed } \\
\text { were never lost, that had origi- } \\
\text { nated with Cranshaw" (p. 138). } \\
\text { "Transmission of the literal content } \\
\text { of the basic information was the } \\
\text { primary task" (p. 138). }\end{array}$ & $\begin{array}{l}\text { "There was no long term interest in } \\
\text { innovating information" (p. 137). "A } \\
\text { preoccupation with basic content of } \\
\text { information continued throughout the } \\
\text { life of this group from generation one } \\
\text { to Generation Seven" (p. 139). } \\
\text { "Cranshaw's group worked well with } \\
\text { three generations but did depart from } \\
\text { this for a long time, while Joan and } \\
\text { Frank were senior members" (p. 139). }\end{array}$ \\
\hline $\begin{array}{l}\text { LIN'S GROUP } \\
\text { \{Hong Kong Chinese }\} \\
\text { [Eastern Heritage } \\
\text { Canadians; } \\
\text { Sociocentric Group] } \\
\text { * } \\
\text { pThe Egocentric (= inde- } \\
\text { pendent generations) versus } \\
\text { Sociocentric (= dependent } \\
\text { generations) distinction is not } \\
\text { know to McFeat and, thus, is } \\
\text { not part of his analysis. } \\
\text { Hence, he cannot understand } \\
\text { the Lin Group interaction } \\
\text { formation of generations nor } \\
\text { the indirect communication } \\
\text { patterns }\end{array}$ & $\begin{array}{l}\text { "The Lin group very early estab- } \\
\text { lished a dyadic pattern, a pattern } \\
\text { of thesis and antithesis with a syn- } \\
\text { thesis always in sight, but rarely } \\
\text { achieved" (pp. 139-140). "The } \\
\text { Chinese expressed interest in the } \\
\text { family as a corporation ... empha- } \\
\text { sized the the resource base of the } \\
\text { family company" [part of novel's } \\
\text { plot] (p. 140). } \\
\text { "Frequent references on the part } \\
\text { of all members of the first genera- } \\
\text { tion to 'what we have decided" } \\
\text { once interpreted content entered } \\
\text { the transmission" (p. 141). } \\
\text { "We found it interesting how will- } \\
\text { ingly the second generation de- } \\
\text { ferred to members of the first de- } \\
\text { spite the heated arguments they } \\
\text { had indulged in, but their defer- } \\
\text { ence was accorded only in the } \\
\text { transmission of basic information" } \\
\text { (p. } 142 \text { ). }\end{array}$ & $\begin{array}{l}\text { "Unlike Buster's group and somewhat } \\
\text { like Cranshaw's, Lin's group tended at } \\
\text { times to collapse all of its interactions } \\
\text { into two-generation directions" (p. } \\
\text { 139). } \\
\text { "Lin's group persisted for Six Genera- } \\
\text { tions" (p. 147). } \\
\text { "When the time came to deal with in- } \\
\text { novated content of information (i.e., to } \\
\text { arrive at a conclusion) Lin asked } \\
\text { Lorna to supply her own version. In } \\
\text { some confusion, but with firmness, } \\
\text { Lorna declined. So systematically } \\
\text { were the innovated results tied into } \\
\text { the interpreted content of information, } \\
\text { and firmly agreed upon by the original } \\
\text { group, that Lorna apparently felt she } \\
\text { was in this way being asked for a } \\
\text { show of loyalty to the group" (p. 140). } \\
\text { "The second group entered passively } \\
\text { and showed great interest in the de- } \\
\text { tails of the narrative; ... it began to } \\
\text { create generations" (p. 141). }\end{array}$ \\
\hline
\end{tabular}


Table 8. (continued vertically, part 3)

\begin{tabular}{|c|c|c|}
\hline \multicolumn{3}{|c|}{ Small Group Culture Structure } \\
\hline GROUP & TEXT & INSTRUCTION \\
\hline 1970 Group & $\begin{array}{l}\text { NO TEXT } \\
\text { A study by members of a student } \\
\text { seminar (23 students) to improve } \\
\text { all department seminars. No text } \\
\text { was referenced, yet the goal was } \\
\text { a Department publication describ- } \\
\text { ing a typical seminar. Personal } \\
\text { experience was abstracted into } \\
\text { discuss-ion. }\end{array}$ & $\begin{array}{l}\text { Innovate new information. } \\
\text { "The task was devised without the } \\
\text { need to establish concrete written in- } \\
\text { formation regarding seminars. This } \\
\text { body of information was felt already to } \\
\text { be known, and the group therefore } \\
\text { proceeded to retrieve information al- } \\
\text { ready assumed to be stored!" (p. 123). } \\
\text { "There were no generational differ- } \\
\text { ences based on control over informa- } \\
\text { tion, therefore no asymmetry based } \\
\text { upon the transmission of information } \\
\text { (sending and reciving) and in the } \\
\text { long run therefore, no generational } \\
\text { differences at all" (p. 124). }\end{array}$ \\
\hline \multicolumn{3}{|c|}{$\begin{array}{l}1970 \text { Group Culture Failure Characteristics: A group without a task quickly becomes an Affiliation Group. } \\
\text { Members proceeded to retrieve already assumed information. "There were no generational differences based on } \\
\text { control over information, therefore no asymmetry based upon the transmission of information (sending and receiv- } \\
\text { ing) and in the long run therefore, no generational differences at all. ... Information circulated through members } \\
\text { which provided no objective context for group formation" (pp. 123-124). "The content of culture not only must be } \\
\text { learned-as everyone has recognized-but also it must be so phrased as to be learnable" (p. 114). }\end{array}$} \\
\hline
\end{tabular}


Table 9. A Communicological Comparison of Egocentric and Sociocentric Cultures

\begin{tabular}{|c|c|}
\hline COMMUNICOLOGY & CULTURE MODELS \\
\hline EGOCENTRIC CULTURE & SOCIOCENTRIC CULTURE \\
\hline U. S. A. & P. R. CHINA \\
\hline Individual "Ego" & Group "Face" \\
\hline Aggregate Form & Organic Form \\
\hline $\begin{array}{l}\text { PARTS make a Whole } \\
\text { "Marbles in a Bag" }\end{array}$ & $\begin{array}{l}\text { WHOLE makes the Parts } \\
\text { "Pile of Salt" }\end{array}$ \\
\hline MEMBER of Groups & GROUP of Members \\
\hline $\begin{array}{l}\text { MESSAGE } \\
\text { gives the } \\
\text { Contact and Code }\end{array}$ & $\begin{array}{c}\text { CODE } \\
\text { Gives the } \\
\text { Context and Message }\end{array}$ \\
\hline $\begin{array}{l}\text { Independence of Form } \\
\text { Is the paramount } \\
\text { Social Goal }\end{array}$ & $\begin{array}{l}\text { Convergence of Form } \\
\text { Is the paramount } \\
\text { Social Goal }\end{array}$ \\
\hline $\begin{array}{c}\text { Communication Entropy } \\
\text { creates } \\
\text { GROUP INSTABILITY }\end{array}$ & $\begin{array}{c}\text { Communication Negentropy } \\
\text { creates } \\
\text { GROUP STABILITY }\end{array}$ \\
\hline $\begin{array}{c}\text { SPACE: Proxemic Code } \\
\text { defines Culture as a World of Static } \\
\text { THINGS }\end{array}$ & $\begin{array}{c}\text { TIME: Chronemic Code } \\
\text { defines Culture as a World of Dynamic } \\
\text { BEHAVIORS }\end{array}$ \\
\hline $\begin{array}{c}\text { Embodied Verbal SPEECH } \\
\text { Is High Context "Space Binding" } \\
\text { Consciousness }\end{array}$ & $\begin{array}{l}\text { Embodied Nonverbal PRACTICE } \\
\text { Is Low Context "Time Binding" } \\
\text { Comportment }\end{array}$ \\
\hline $\begin{array}{c}\text { Expression: } \\
\text { Understanding of one SELF } \\
\text { ("Me") }\end{array}$ & $\begin{array}{c}\text { Perception: } \\
\text { Understanding of the OTHERS } \\
\text { ("Them") }\end{array}$ \\
\hline $\begin{array}{c}\text { DIRECT } \\
\text { COMMUNICATION: } \\
\text { - NAME specifies Individual PERSON } \\
\text { - GIVEN NAMES control the formality } \\
\text { level of Interpersonal Interactions } \\
\text { - First Name Reference Preference } \\
\text { - DAY } \rightarrow \text { Month } \rightarrow \text { Year } \longrightarrow \text { Succesors }\end{array}$ & $\begin{array}{c}\text { INDIRECT } \\
\text { COMMUNICATION: } \\
\text { - NAME specifies Family GROUP } \\
\text { - "RELATIONSHIP" NAMES control } \\
\text { the level of Interpersonal Interactions } \\
\text { - Family Name Reference Preference } \\
\text { - YEAR } \rightarrow \text { Month } \rightarrow \text { Day }>\text { Ancestors }\end{array}$ \\
\hline
\end{tabular}




\section{Acknowledgements}

The original version of this paper was presented at the International Communicology Institute Fifth Summer Conference on "Human Understanding: The Matrix of Communication and Culture" held in Jelenia Góra, Silesia, Poland, 15-22 July 2011 under the direction of Professor Zdzisław Wąsik. I wish to thank all participants for their valuable comments and suggestions, especially Professor Paul Bouissac.

\section{References}

Bühler, Karl 1934. Sprachtheorie. Jena: Gustav Fischer, 1934: reprint 1982, trans. Donald R. Goodwin, Theory of Language: The Representational Function of Language. Amsterdam: John Benjamins, 1990

Cassirer, Ernst 1923. Philosophie der symbolischen Formen, 3 vols. Berlin: Bruno Cassirer. Vol. 1, Die Sprache (1923); Vol. 2, Das mythische Denken (1925); Vol. 3, Phänomenologie der Erkenntnis (1929). Reprinted: 3 vols. Darmstadt: Wissenschaftliche Buchgesellschaft, 1964, trans. Ralph Manheim, The Philosophy of Symbolic Forms. New Haven, CT: Yale University Press, 1953-1957. Vol. 1, Language (1953); Vol. 2, Mythical Thought (1955); Vol. 3, The Phenomenology of Knowledge (1957)

Cassirer, Ernst, 1942. Zur Logik der Kulturwissenschaften: Fünf Studien in Götesborgs Högskolas Arsskrift 48 (1942) 1-139, trans. S. G. Lofts, The Logic of the Cultural Sciences: Five Studies. New Haven, CT: Yale University Press, 2000; this edition replaces the earlier trans. by Clarence Smith Howe, The Logic of the Humanities. (ale University Press, 1960

Cassirer, Ernst, 1946. Sprache und Mythos, Number VI of Studien der Bibliothek Warburg, ed. Fritz Saxl, trans Susanne K. Langer, Language and Myth. New York: Harper and Brothers, 1946; Dover edition, 1953 
Cassirer, Ernst, 1979. Symbol, Myth, and Culture: Essays and Lectures of Ernst Cassirer, 1935-1945, ed. Donald Phillip Verene. New Haven: Yale University Press; Italian trans., Simbolo, mito e cultura. Rome and Bari: Laterza, 1981; Japanese trans., Kyoto: Mionerva, 1985

Cassirer, Ernst, 1995. Zur Metaphysik der symbolischen Formen, ed. John Michael Krois, Vol. 1 of Ernst Cassirer, Nachgelassene Manuskripte und Texte, ed. John Michael Krois and Oswald Schwemmer. Hamburg: Felix Meiner, 1995, trans. John Michael Krois, The Philosophy of Symbolic Forms, Vol. 4, The Metaphysics of Symbolic Forms. New Haven, CT: Yale University Press, 1996

Crystal, David, 1997 (ed.). Cambridge Encyclopedia of Language. New York: Cambridge University Press

Giorgi, Amedeo, 2009. The Descriptive Phenomenological Method in Psychology. Pittsburgh, PA: Duquesne University Press

Holenstein, Elmar, 1974. Jakobson, ou sur le structuralisme phénoménologique. Paris: Editions Seghers, trans. Catherine Schelbert and Tarcisius Schelbert, Roman Jakobson's Approach to Language: Phenomenological Structuralism [from German Habilitationschrift, Zurich 1974]. Bloomington and London: Indiana University Press, 1976

Husserl, Edmund, 1960. Cartesian Meditations: An Introduction to Phenomenology. The Hague: Martinus Nijhoff, trans. Dorion Cairns based primarily on a text ed. S. Strasser in Husserliana, vol. 1. Haag: Martinus Nijhoff, 1951.

Ihde, Don, 1977. Experimental Phenomenology: An Introduction. New York, NJ: Capricorn Books; G. P. Putnam's Sons

Jakobson, Roman Osipovîch, 1962-2002. Selected Writings, 9 vols. Vol. 1, Phonological Studies, 1962, 2nd ed. 1971, 3rd ed. 2002; Vol. 2, Word and Language, 1971; Vol. 3, Poetry of Grammar and Grammar of Poetry, ed. Stephen Rudy, 1981; Vol. 4, Slavic Epic Studies, 1966; Vol. 5, On Verse, Its Masters and Explorers, ed. Stephen Rudy and Martha Taylor, 1979; Vol. 6, Early Slavic Paths and Crossroads: Part 1 and Part 2, ed. Stephen Rudy, 1985: Vol. 7, Contributions to Comparative Mythology; Studies in Linguistics and Philology, 1972-1982, ed. Stephen Rudy, 1985; Vol. 8, Completion Volume One: Major Works, 1976-1980, ed. Stephen Rudy, 1988; Vol. 9, A Complete Bibliography of his Writings, compiled and ed. Stephen Rudy, 1990. Berlin: Mouton de Gruyter [Unless noted, volumes were edited by Jakobson.]

Jaspers, Karl, 1913, 1923, 1946. Allgemeine Psychopathologie. Berlin, Gottingen and Heidelberg: Springer Verlag, trans. $7^{\text {th }}$ ed. J. Hoenig and Marian W. Hamilton, General Psychopathology. Manchester, UK: Manchester University Press, 1963

Jaspers, Karl, 1932, 1948, 1956. Philosophe. Berlin, Gottingen and Heidelberg: Springer Verlag,, trans. E. B. Ashton, Philosophy, 3 vols. Chicago, IL: University of Chicago Press, 1970 
Lanigan, Richard L., 1980. Thomas E. S. McFeat, Lecture Notes from the Seminar: SelfOrganizing Group Cultures, International Summer Institute for Semiotic Studies, Paul Bouissac, Director, University of Toronto, 3-24 June 1980 (Unpublished)

Lanigan, Richard L., 1984. Semiotic Phenomenology of Rhetoric: Eidetic Practice in Henry Grattan's Discourse on Tolerance. Current Continental Research, No. 203. Washington, DC: Center for Advanced Research in Phenomenology; University Press of America

Lanigan, Richard L., 1988. Phenomenology of Communication: Merleau-Ponty's Thematics in Communicology and Semiology. Pittsburgh: Duquesne University Press

Lanigan, Richard L., 1992. The Human Science of Communicology. Pittsburgh, PA: Duquesne University Press

Lanigan, Richard L., 1995a. From Enthymeme to Abduction: The Classical Law of Logic and the Postmodern Rule of Rhetoric: 49-70, notes 278-283. Recovering Pragmaticism's Voice: The Classical Tradition, Rorty, and the Philosophy of Communication, eds. Lenore Langsdorf and Andrew R. Smith. Albany: State University of New York Press

Lanigan, Richard L., 1995b. A Good Rhetoric Is Possible: Ricoeur's Philosophy of Language as a Phenomenology of Discourse in the Human Sciences: 309-326, Ricoeur reply, 327-329. The Philosophy of Paul Ricoeur, ed. Lewis Hahn. The Library of Living Philosophers; Chicago: The Open Court Publishing Co.

Lanigan, Richard L., 1995c. Time Binding: The Conjunction of Semiotics and Communicology. Cruzeiro Semiótico 22-25 (1995b) 325-336.

Lanigan, Richard L., 2005. Fabulous Political Semiotic: The Case of George Orwell's Animal Farm: 421-435. Semiotics 2003: Semiotics and National Identity, ed. Rodney Williamson, Leonard G. Sbrocchi, and John Deely. Ottawa, Canada: Legas Publishing

Lanigan, Richard L., 2006. Crossing Out Normative Boundaries in Psychosis: A Social Semiotic Passage in Dickens' Bleak House. S-European Journal of Social Semiotics, Special Issue on Sociosemiotics II. Wein, Austrai: Institut für Sozio-Semiotische Studien

Lanigan, Richard L., 2009. Cosmology and Communicology in an Internet World: Semiotic Perspectives of the East (PRC) and the West (USA). Chinese Semiotic Studies 1 (June 2009) 228-254

Lanigan, Richard L., 2010. The Verbal and Nonverbal Codes of Communicology: The Foundation of Interpersonal Agency and Efficacy: 102-128. Communicology: The New Science of Embodied Discourse, ed. Isaac E. Catt and Deborah Eicher-Catt. Madison, NJ: Fairleigh Dickinson University Press

Lanigan, Richard L., 2010a. Proto-Phenomenology, Rationality, and Schizophrenia. Second Annual Conference, Interdisciplinary Coalition of North American Phenomenologists (ICNAP). Brock University, St. Catharines, Canada, 28-29 May 
Lanigan, Richard L., 2010b. Mind-Body Problem. Encyclopedia of Identity, 2 vols., ed. Ronald L. Jackson II. Thousand Oaks, CA: Sage Publications 1: 450-454

Lanigan, Richard L., 2011a. Small Group Communicology: Nominal Group Technique for Conflict Management in Work Groups: 124-139. People and the Value of an Organization, ed. Felicjan Bylok and Leszek Cichobłaziński. Częstochowa. Poland: Sekcja Wydawnictwa Wydziału Zarządzania Politechniki Częstochowskiej

Lanigan, Richard L., 2011b. On Homeworld and Community Models of the City: The Communicology of Egocentric and Sociocentric Cultures in Urban Semiotics: 11-46. Unfolding the Semiotic Web in Urban Discourse, ed. Zdzisław Wąsik with Diana Teters. Frankfurt am Main: Peter Lang Internationaler Verlag der Wissenschaften

Lanigan, Richard L., 2012a in press. Absolute Human: Communicology and Intentionality of Embodiment. Metamorphoses of the Absolute, ed. Daina Teters. Riga: Latvian Academy of Culture

Lanigan, Richard L., 2012b in press. Familiar Frustration: The Japanese Encounter with Navajo (Diné) "Code Talkers" in World War II. [Book Title Pending] [Philologia Wratislaviensia: From Grammar to Discourse, No. 4], ed. Zdzisław Wąsik. Frankfurt am Main: Peter Lang Internationalaler Verlag der Wissenschaften

Lanigan, Richard L., 2012c. The Logic of Phenomena: Semiotic Structures of West and East in Communicology and Culture. Chinese Semiotic Studies 6 ( June 2012) 39-77

Lévi-Strauss, Claude, 1958, 1967. The Structural Study of Myth: 202-228. Structural Anthropology, Vol. 1, trans. C. Jacobson and B. G. Schoepf. Garden City, NY: Anchor/Doubleday Books

Mead, Margaret, 1970. Culture and Commitment: A Study of the Generation Gap. Garden City, NJ: Doubleday and Co.

Merleau-Ponty, Maurice, 1945. Phénoménologie de la Perception. Paris: Éditions Gallimard, trans. Donald A. Landes, Phenomenology of Perception. New York: Routledge, 2012.

Merleau-Ponty, Maurice, 1960. Sur la Phénoménologie du Langage: 105-122. Signes. Paris: Éditions Gallimard, trans. Richard C. McCleary. Evanston, IL: Northwestern University Press, 1964: 84-97. Original paper presented at the first Colloque international de phńomńologie, Brussels, 1951.

Merleau-Ponty, Maurice, 1964. Le Visible et L'Invisible. Paris: Éditions Gallimard, ed. Claude Lefort, trans. Alphonso Lingis. The Visible and the Invisible. Evanston, IL: Northwestern University Press, 1968

McFeat, Tom [Thomas E. S.], 1974. Small-Group Cultures. New York, NY: Pergamon Press, Inc.

McFeat, Thomas E. S., 1979. The Communication of Culture: Models of Learning for Troops and Children. Toronto Semiotic Circle: Monographs, Working Papers, and 
Prepublications: Monograph No. 4. Toronto, Canada: Victoria University; University of Toronto

McFeat, Tom [Thomas E. S.] (ed.), 2002. Indians of the North Pacific Coast. Carleton Library No. 25. Montreal: McGill-Queen's University Press; Seattle: University of Washington Press

Peirce, Charles Sanders, 1931-1958. Collected Papers of Charles Sanders Peirce. Vol. 1: Principles of Philosophy; Vol. 2: Elements of Logic; Vol. 3: Exact Logic (Published Papers); Vol. 4: The Simplest Mathematics; Vol. 5: Pragmatism and Pragmaticism; Vol. 6: Scientific Metaphysics, ed. Charles Hartshorne and Paul Weiss. Cambridge, MA: Harvard University Press, 1931-1935; Vol. 7: Science and Philosophy; Vol. 8: Reviews, Correspondence, and Bibliography, ed. Arthur W. Burks,1958; all eight vols. in electronic form ed. John Deely. Charlottesville, VA: Intelex Corporation, 1994. Dating within the CP (which covers the period in Peirce's life,1839-1914) is based principally on the Burks Bibliography at the end of CP 8 . Reference by codex custom is to volume and paragraph number(s) with a period in between.

Roberts, J.M., 1951. Three Navajo Households: A Comparative Study of Small-Group Culture. Papers of the Peabody Museum of American Archaeology and Ethnology, Harvard University XL (1951) 3

Roberts, J.M., 1964. The Self-Management of Cultures. Explorations in Cultural Anthropology: Essays in Honor of George Peter Murdock, ed. W. Goodenough. New York, NY: McGraw-Hill

Sebeok, Thomas A. 1982. Pandora's Box: Why and How to Communicate 10,000 Years into the Future. General Semantics Bulletin [Alfred Korzybski Memorial Lecture, Institute of General Semantics] 49 (1982) 23-45

Wilden, Anthony, 1972, 1980. System and Structure: Essays in Communication and Exchange, 2nd. ed. London, UK: Tavistock Publications Ltd.

Wilden, Anthony, 1987. The Rules Are No Game: The Strategy of Communication. New York, NY: Routledge and Kegan Paul 